\title{
PAY, PERFORMANCE AND GOVERNANCE IN IRISH PLCS
}

\author{
Tongyu Cao, Ray Donnelly and James McCarthy \\ University College Cork
}

\begin{abstract}
$T_{\text {o }}^{h}$ his study finds that company size is a major determinant of chief executive officer (CEO) compensation in Ireland. There is little evidence of a relation between CEO remuneration and company performance. However, several corporate governance variables are related to remuneration in a manner that suggests that good governance reduces executive pay. There is also some evidence of a distinctive 'US effect', in that companies that are more exposed to business practices in the United States (US) have higher remuneration, particularly in the form of executive stock options.
\end{abstract}

\section{INTRODUCTION}

There is an extensive body of research in the area of executive compensation and firm performance. Much has been made of the high pay awards that have frequently been made to top company executives. With recent corporate scandals, corporate governance and the agency problem have attracted much public interest. The issue of executive pay has featured in front-page headlines, cover stories and television news shows, particularly during the bull market of the 1990s. ${ }^{1}$ More recently, news that bonuses have continued to be paid to executives of organisations that have underperformed to such an extent that they had to be bailed out by governments has perplexed the general public. This has led to calls for chief executive officers' (CEOs) pay to be increasingly linked to stock price performance.

This study explains cross-sectional differences in CEO compensation in Irish public limited companies (plcs). While pay practices vary across firms and industries, most CEO pay packages contain four basic components: a base salary (including pension), an annual bonus tied to accounting performance, stock options 
Cao, Donnelly and McCarthy

and long-term incentive plans. This study examines the basic salary and bonus (cash compensation) and then separately analyses executive stock options (ESOs). Specifically, we examine the basic fixed remuneration (salary, pension and bonus) of the $\mathrm{CEO}$ and then separately the value of his/her ESOs. There is a perception that many executives have profited despite the decline of the stock market performance of their companies. A primary objective is to examine the relation between CEO remuneration and firm performance. Good corporate governance should limit excessive pay rewards to executives. In addition, it should improve the pay-performance relation. This study also addresses these questions.

While there has been much research in this area, producing widely varying results, there has been no published empirical research completed in an Irish context. Ireland is an interesting location for such a study given the extent of direct investment by US companies in the country and its replication of corporate governance practices from the United Kingdom (UK). There is a view that US companies export their 'excessive' pay practices to executives of foreign subsidiaries. This then puts pressure on the pay policies of local competitors (Conyon, Peck, Read and Sadler, 2000). Additionally, foreign companies that acquire US subsidiaries face substantial internal pay differences which are usually resolved by increasing the home country's executive pay level.

Irish plcs follow a very similar regulatory environment to that of their UK counterparts. Stock exchange rules dictate that all Irish plcs must disclose a statement in their annual reports on their corporate governance practices which (a) explains how they apply the principles of the UK Corporate Governance Code and (b) states whether or not they comply with the code and, if the latter is the case, explain the reasons for non-compliance. Thus we have an opportunity to examine the impact of UK governance practices in a setting where US pay practices are likely to have a major influence. The study addresses this issue by constructing an indicator variable to capture the potential influence of US norms on a CEO's pay. We report that this indicator variable has a positive and significant affect on CEO pay in the form of ESOs. There is little evidence of a relation between company performance and the remuneration of the CEOs in Irish plcs and that evidence which we do find demonstrates an asymmetry in which good performance is rewarded while there is no relation between compensation and poor performance. We report that a higher standard of corporate governance generally reduces CEO compensation.

\section{LITERATURE REVIEW}

\section{Executive Compensation and Performance}

The separation of ownership from control requires that shareholders monitor managers or alternatively incentivise them appropriately to ensure that they always act in the best interests of the shareholders. Theoretical work in agency literature indicates that when the principal (in this case the shareholder) has complete information about the efforts of the agent (in this case the CEO), monitoring is the most efficient solution (Holmstrom, 1979). However, when information asymmetries are such as to ensure that the agent's efforts are not easily observed, the principal will be better 
off transferring risk to the agent by basing the CEO's contract on observable performance outcomes (Tosi, Werner, Katz and Gomez-Mejia, 2000). Incentives can be provided in part by performance-based compensation packages. However, Lazear (1989) argues that contingent performance-based compensation schemes such as bonuses and share options depend crucially on the assumption that direct monitoring of executives is quite costly. Monitoring of management can be expensive. However if cheap monitoring is available then both shareholders and managers might prefer non-contingent compensation systems, such as a fixed salary.

Early studies generally fail to find a strong pay-performance relation. Jensen and Murphy (1990a, p. 138) state that in the US '[i]n most publicly held companies, the compensation of top executives is virtually independent of performance. On average, corporate America pays its most important leaders like bureaucrats.' They also state that if CEOs are paid like bureaucrats, 'is it any wonder then that so many CEOs act like bureaucrats rather than the value-maximizing entrepreneurs companies need to enhance their standing in world markets?' (Jensen and Murphy, 1990a, p. 138). Authors such as Garen (1994) and Haubrich (1994) agree with Jensen and Murphy (1990b) and argue that the alignment of the interests of executives and shareholders could be stronger. Haubrich (1994) also points out that variation in the risk aversion of CEOs could allow a very large range of pay-performance sensitivities to be optimal. A relatively low pay-performance sensitivity may be optimal for a risk-averse CEO but it becomes sub-optimal for a risk-taking CEO.

The inclusion of executive stock options (ESOs) in managers' compensation produces a more performance sensitive remuneration package. For example, when a more comprehensive measure of remuneration that includes ESOs is used to measure management compensation, the impact of firm size on remuneration is attenuated and the impact of company performance enhanced (Murphy, 1985). There have been major changes in the manner in which US corporations reward their executives since Jensen and Murphy's (1990b) study. The percentage of US firms using share option plans to reward their executives has grown from 70 per cent in 1980 to 97 per cent in 1997 (Conyon and Murphy, 2000). Within this period there were dramatic increases in the early 1980s and the early 1990s, in the latter case especially for small and midcap (medium-sized) companies (Conyon and Murphy, 2000).

Early UK evidence reports a relation between pay and performance that is significant but much weaker than the relation between pay and size (e.g. Cosh, 1975). Gregg, Machin and Szymanski (1993) report evidence of a weak and inconsistent relationship between pay and performance during the period 1983-1991. Gregg, Jewell and Tonks (2005) report that pay is more sensitive to performance when stock returns are relatively high, but less sensitive when stock returns are low. This would suggest that overall there is a weak relationship between pay and performance. Over the time period studied (1995-2002), executive pay increased greatly but with little relationship to firm performance. Using a sample of large UK firms, Main, Bruce and Buck (1996) report low pay-performance sensitivity when executive pay is measured by salary plus bonus. However, when the value of stock options is included in pay the pay-performance sensitivity increases significantly. Benito 
and Conyon (1999) provide evidence that the relation between cash compensation and performance, though much weaker than the relation between performance and firm size, is significant and strengthened between 1985 and 1995.

There are a number of potential reasons for the failure to find a strong relation between executive pay and performance. Tosi et al. (2000) suggest objective performance measures found in executive compensation literature may be considered inadequate for evaluation purposes by those who are responsible for setting executive compensation. It has been suggested that 'perhaps the performance criteria may be deficient because they typically tap only a small portion of the CEO's job performance requirements, and therefore contain a large amount of noise, making unambiguous causal attributions for observed results very difficult' (Tosi et al., 2000, p. 331). Accordingly, more subjective evaluation processes are used to assess the executives' contributions and the objective measures employed in academic research do not measure the performance of executives in the same way as those responsible for determining their remuneration.

Ezzamel and Watson (2002) argue that pay comparability (i.e. the pay of a CEO versus that of other CEOs and the comparison between CEO and other executive directors in the same firm), both externally and internally, is an important determinant of executive pay. Drawing on, inter alia, equity theory, hierarchical pecking order theory and figurehead theory, they argue that external and internal labour market comparisons are important in setting executive remuneration. Minimising deviations from the 'going rate' facilitates the avoidance of problems pertaining to team-building, motivation, retention, recruitment and external credibility. In such a labour market, given risk aversion, the optimal employment contract is expected to include a fixed salary component that is wholly independent of firm performance.

\section{Executive Compensation and Corporate Governance}

Academic research pertaining to the relation between governance and pay tends to focus on the relations between board structure and pay as well as between ownership structure and pay. The influence of corporate governance reforms on the above two relationships also attracts academic scrutiny. Since agency theory suggests that the separation of ownership from control gives executives the opportunity to expropriate wealth from the shareholders of the firms they manage, we begin our consideration of governance and pay with an examination of ownership structure and its influence on executive compensation.

Large individual owners can effectively monitor executives and reduce agency costs because of their significant shareholdings and relatively lower costs of monitoring compared with more dispersed shareholders. Without major shareholders who exert vigilance, executives tend to pursue their own interests, such as employment security, size and prestige of the firm, personal pay and pension arrangements, rather than maximising shareholder wealth (Hambrick and Finkelstein, 1995). Sapp (2008) reports that large external shareholders influence executive compensation. Conyon and Leech (1994) show that there is some evidence that firms with high ownership concentration had lower levels of top pay for a sample period in the mid1980s, but they find no evidence that the level of ownership concentration affected growth in executive pay between 1983 and 1986. They also report that the potential 
monitoring effects of pension funds and insurance companies had no effect on the growth in top pay during the mid-1980s. However, Ozkan (2007) and Core, Holthausen and Larcker (1999) report that institutional block ownership levels have a significant and negative impact on CEO compensation. This suggests active monitoring by these parties. Hartzell and Starks (2003) find a significantly negative relation between the level of institutional ownership and the level of executive compensation. Dong and Ozkan (2008) report that, while institutional ownership does not influence executive compensation, ownership by dedicated institutions or longhorizon institutions does reduce compensation. These results suggest that large shareholders and institutional shareholders, particularly institutional activists, perform a monitoring role in mitigating the agency problem between shareholders and managers and so reduce management compensation.

Since managerial ownership can substitute for incentivised compensation contracts, the relation between managerial ownership and compensation has also attracted attention. The evidence on this issue has been mixed. Allen (1981) and Core et al. (1999) provide evidence that the level of CEO compensation is a decreasing function of the amount of shares held by the CEO. In the UK, Ozkan (2007) finds that the relationship between executive ownership levels and equity-based pay is negative and statistically significant. This is consistent with agency theory, in that as managers' stock ownership increases, managers' interests become more aligned with those of shareholders and there is less need for managers to have equity-based incentive compensation. However, Holderness and Sheehan (1988) find that managers who are majority shareholders in publicly traded US companies receive marginally higher salaries than other officers. This means that CEOs with a high equity ownership could have more controlling power and use corporate resources to benefit themselves, such as providing themselves with higher compensation. Taken together, these results suggest a possible non-linear relation between managerial ownership and compensation: the latter decreases initially as managerial ownership increases but increases following management entrenchment when managerial ownership is high.

Sapp (2008) reports that a less independent board of directors is related to increased compensation. However, Fernandes (2008) reports that executive remuneration is higher when companies have more non-executive directors. Furthermore, there is a stronger relation between performance and pay in companies with no nonexecutive directors. Conyon and Peck (1998) and Core et al. (1999) report similar results. Ozkan (2007) also reports a positive relation between the proportion of the board comprised of non-executives and executive pay. He considers this evidence consistent with that of Franks, Mayer and Renneboog (2001), which suggests that non-executive directors in the UK do not perform a disciplinary function and instead help entrench management.

Other aspects of board structure that are related to executive compensation include board size and $\mathrm{CEO} /$ chair duality (i.e. one person acting as both CEO and chairperson of the board of management). The empirical evidence generally suggests that compensation is either unrelated to $\mathrm{CEO} /$ chair duality or is reduced by a separation of these roles. Conyon and Murphy (2000) and Core et al. (1999) report that separating the offices of $\mathrm{CEO}$ and chairperson reduces executive compensation, 
Cao, Donnelly and McCarthy

but Benito and Conyon (1999) find no relation between CEO/chair duality and compensation.

There was a perception in the UK in the early 1990s that directors' remuneration packages were esoteric and excessive. The establishment of the Cadbury Committee was partially motivated by concerns pertaining to executive compensation determination. A major recommendation of Cadbury (1992) was the transfer of compensation-setting from management to a remuneration committee of the board of management to be comprised mainly of outside directors. Cadbury (1992) also advocated full disclosure of the total remuneration of the directors, the chairperson and the highest paid director. The Greenbury Committee, which reported in 1995, was set up to further examine the issue of executive remuneration. The committee's report suggested 'greater disclosure of executive pay and stronger scrutiny over the setting of executive compensation and emphasised that incentive-based compensation should have strict performance criteria' (Gregg et al., 2005). The findings of the committee are still reflected in the UK Corporate Governance Code (Financial Reporting Council, 2010).

Studies post-Cadbury (1992) and Greenbury (1995) have shown the majority of firms have complied with the suggested recommendations, such as splitting the roles of chairperson and $\mathrm{CEO}$ and setting up a number of committees such as a remuneration committee and a nomination committee. It's worth noting that the Cadbury Report (1992) never advocated the need for changes in the level of executive pay. Rather it addressed the pay-setting process in order to more closely align executive and shareholder interests. The sensitivity of pay to performance should have increased in the post-Greenbury (1995) period. However, studies that examine this issue show that pay was largely unaffected, except for smaller firms. Girma, Thompson and Wright (2007) provide little evidence of increased pay-performance sensitivity in the post-Cadbury (1992) era. Benito and Conyon (1999) also find very little evidence of corporate governance changes affecting the level and structure of CEO pay. However, the latter study does provide evidence that executive remuneration is positively related to firm size and performance, with size being the dominant factor. It appears that governance reform has done very little to change the level of pay or alter pay-performance sensitivity in the UK.

\section{Other Determinants of Executive Compensation}

Tosi et al. (2000) suggest managerialism as an alternative theoretical framework through which to view the pay-performance relation. They argue that executives are more interested in increasing company size than increasing shareholder wealth. Increasing size can reduce risk to executives and can also provide, with some justification, an alternative benchmark for pay. Given that firm size is more easily controlled than firm value, executives prefer to link pay with size. Managers are not the only group who link their pay to the size of the firm. Outside professional compensation consultants typically stratify firms based on size (Baker, Jensen and Murphy, 1988). Larger firms usually have higher compensation levels and higher pay increases (Boyd, 1994; Finkelstein and Boyd, 1998). Larger firms may employ better qualified and, as a result, better paid managers. In the US, Rosen (1982) and Kostiuk (1990) provide evidence that a 10 per cent increase in firm size will result in 
CEO pay increasing by about 3 per cent. Gregg et al. (2005) find that firm size is the dominant variable in determining the level of executive compensation for UK firms.

Tosi et al. (2000) show that firm size explains about 40 per cent of the variance in total CEO pay, almost nine times more than the most highly correlated performance measure. If a CEO's remuneration is driven more by size than performance, then this creates a moral hazard problem as managers will have incentives to pursue merger and acquisition activities regardless of any potential benefits to shareholders.

The literature on the pay-performance relation is mixed and often contradictory. It is clear from the literature review that performance should influence pay but does not always appear to do so. Evidence from the US and the UK suggest that the relation between performance and pay is becoming stronger in recent years. However, Gregg et al. (2005) suggest that the pay-performance relation is only strong when performance is good. There appears to be a stronger relation between pay and performance when stock-related compensation is included in total pay. Size invariably dominates performance in determining executive pay. There is also some evidence that corporate governance practices influence pay. For example, ownership structure has an influence on pay. Strong governance should ensure that management's and shareholders' interests are aligned and compensation is appropriate. An ownership structure with active shareholders and an independent board of directors should ensure that the shareholders do not overpay the executives who run their company on their behalf. In addition, the incentives provided by executive compensation can be viewed as a substitute for the monitoring provided by strong corporate governance.

This study examines the factors that determine executive compensation in Ireland. In the case of ESOs, some studies report that their use enhances the payperformance relation while others (e.g. Byard and Li, 2005) suggest that managers opportunistically capture the benefits of ESOs while not necessarily providing improved performance. While the relation between pay and performance has been studied in many countries, the current study is the first of its kind to focus on the Irish market. In addition, little attention has been paid to the influence of governance on the pay-performance relation. The empirical analysis includes explanatory variables that reflect the three major determinants of CEO remuneration considered in the literature: performance, governance and firm size. In addition, we include a variable designed to capture the potential influence of US business norms on CEO compensation in Ireland.

\section{EMPIRICAL ANALYSIS}

The primary research questions that this study addresses pertain to the relationship of the CEO's compensation with both performance and governance. These relationships are examined within a linear model designed to explain cross-sectional variation in compensation. Additional issues explored within the model are the impact that governance has on the compensation-performance relation and the influence of US business norms. Finally, tests are undertaken to investigate possible non-linearities and asymmetries in the performance compensation relationship. 
The basic model used in the study is outlined in Equation (1) below:

$$
\begin{aligned}
\ln (\text { Compensation })_{\mathrm{t}} & =\alpha_{0}+\sum_{k=2001}^{2003} \alpha_{k}+\beta_{1} \ln (\mathrm{TA})_{\mathrm{t}-1}+\beta_{2} \text { Performance }_{\mathrm{t}-1}+\beta_{3} \text { BSIZE }_{\mathrm{t}-1} \\
& +\beta_{4} \mathrm{NED}_{\mathrm{t}-1}+\beta_{5} \mathrm{MAN}_{\mathrm{t}-1}+\beta_{6} \mathrm{BLK}_{\mathrm{t}-1}+\beta_{7} \mathrm{LEV}_{\mathrm{t}-1}+\beta_{8} \mathrm{DUAL}_{\mathrm{t}-1} \\
& +\beta_{9} \mathrm{US}_{\mathrm{t}-1}+\beta_{10} \mathrm{FIN}_{\mathrm{t}-1}+\mathrm{e}_{\mathrm{t}-1}
\end{aligned}
$$

Where,

$\ln ($ Compensation $)=$ the natural $\log$ of the remuneration of the CEO: $\ln (P A Y)$, or ESO, the natural $\log$ of the value of executive stock options

$\ln (T A)=$ the nature log of total assets: firm size

Performance $=$ cumulative abnormal return $(\mathrm{CAR})$ or return on equity $(\mathrm{ROE})$

$B S I Z E=$ the number of directors on the board

$N E D=$ the proportion of the board comprised of non-executive directors

$M A N=$ the percentage of the total equity capital owned by the executive directors

$B L K=$ the percentage of the total equity capital owned in blocks of greater than 3 per cent by outside (non-management) shareholders

$L E V=$ the debt-to-equity ratio

$D U A L=$ a dummy variable which takes the value of 1 when the positions of chairperson and CEO are held by different persons

US = a dummy variable which takes the value of 1 if the company has (a) significant business interests in the US or (b) has at least one US national on its board

$F I N=$ an indicator variable which takes the value 1 if firm $i$ is a financial or property firm and zero otherwise

$t$ represents the years 2002 to 2005 and $a_{k}$ is a dummy variable representing the years 2001, 2002 and 2003

Note all of the independent variables are computed in the year before the dependent variable to avoid the endogeneity problem that is pervasive in governance research. The model includes performance, governance variables and an indicator variable for significant US business interests. Since compensation is often industry specific the model would ideally include industry dummies or use industry-adjusted data. However, we note that many papers drop industries where there are insufficient observations. For example Rajgopal, Shevlin and Zamora (2006) don't retain industries with less than ten observations (companies or companies per year). We cannot adopt the same approach here since no industry in our sample has as many as ten observations. However, to provide some control for a potential industry effect we include an indicator for the financial services industry since it is clearly distinctive from the other industries in the economy. CEO risk aversion, which may be proxied by non-firm specific wealth, will affect the optimal design of incentives (Becker, 2006). We do not control for variation in CEO risk aversion since data on their non-firm wealth are not available to us. In any event, Baker and Hall (2002) claim that wealth dispersion in the US is not large enough to give rise to non-trivial cross-sectional variation relative to firm specific variables. Accordingly, we feel safe 
in concluding that disparate risk aversion among CEOs in Ireland is unlikely to be a significant factor but acknowledge that this is ultimately an empirical question.

The hypotheses tested are:

$\mathbf{H}_{1}$ : Executive compensation is positively related to performance: $\beta_{2}$ is positive.

$\mathbf{H}_{2}$ : Executive compensation is positively related to firm size: $\beta_{1}$ is positive.

$\mathbf{H}_{3}$ : Enhanced shareholder monitoring and control as reflected in a company's corporate governance mechanisms reduce executive compensation. This hypothesis is tested with reference to the sign and significance of $\beta_{3}-\beta_{8}$.

$\mathbf{H}_{4}$ : Improved governance enhances the pay-performance relation. This hypothesis is tested by adding a performance and governance interaction term to Equation 1 (further details below).

$\mathbf{H}_{5}$ : Connections with the United States increases the level of compensation paid to Irish CEOs: $\beta_{9}$ is positive.

$\mathbf{H}_{6}$ : The pay-performance relation is asymmetric. This is tested by separating negative and positive performance so that the model is altered to become:

$$
\begin{aligned}
\ln (\text { Compensation })_{\mathrm{t}} & =\alpha_{0}+\sum_{k=2001}^{2003} \alpha_{k}+\beta_{1} \ln (\mathrm{TA})_{\mathrm{t}-1}+\beta_{2} \mathrm{D} 1 * \text { Performance }_{\mathrm{t}-1}+\beta_{3} \mathrm{D} 2 \\
& * \text { Performance }_{\mathrm{t}-1}+\beta_{4} \mathrm{BSIZE}_{\mathrm{t}-1}+\beta_{5} \mathrm{NED}_{\mathrm{t}-1}+\beta_{6} \mathrm{MAN}_{\mathrm{t}-1}+\beta_{7} \mathrm{BLK}_{\mathrm{t}-1} \\
& +\beta_{8} \mathrm{LEV}_{\mathrm{t}-1}+\beta_{9} \mathrm{DUAL}_{\mathrm{t}-1}+\beta_{10} \mathrm{US}_{\mathrm{t}-1}+\beta_{11} \mathrm{FIN}_{\mathrm{t}-1}+\mathrm{e}_{\mathrm{t}-1}
\end{aligned}
$$

$\mathrm{D} 1$ is equal to 1 if performance is $<0$, otherwise zero

$\mathrm{D} 2$ is equal to 1 if performance is $\geq 0$, otherwise zero

All the companies listed on the Irish Stock Exchange for which the requisite data is available for the four years 2001-2004 enter the initial sample. Some companies are only present for one year if they left or joined the market in the period 2001 to 2005. Companies are eliminated from the initial sample if they did not have at least two years of data, which is required by the model outlined in Equation (2) above. Companies are also eliminated from the sample if there are problems in identifying the exact payments to the top executives and determining the executive compensation due to variations in the manner in which firms report and present data and changes in rules over the years. The final sample comprises 45 unique companies. Although the final sample size is small in relation to comparable studies in the UK and the US, it is still fairly representative given the limited size of the Irish Stock Exchange (ISEQ). For example, the Annual Statistical Review of the Irish Stock Exchange (2003) reports that there were 59 securities issued by 51 individual Irish and international companies on the Official List in $2004 .{ }^{2}$ Of the remaining 51 'companies', four (AICF, Aviva, 
Diageo, Tesco) are international and have their main quotation elsewhere so were not considered for inclusion in the sample. There were thirteen additional companies on the ITEQ (the dedicated market for technology stocks in Ireland), the Exploration Securities Market (ESM) and the Developing Companies Market (DSM). These companies have less demanding disclosure requirements which preclude most of them from our sample. We still manage to include five of the largest of these companies in the sample. ${ }^{3}$ The combined market capitalisation of the ITEQ, ESM and DSM markets in 2004 was $€ 1,182$ million or 1.4 per cent of the capitalisation of the Irish stock market index (the ISEQ), which was $€ 80,868$ million. We estimate that our sample of $45 \mathrm{com}$ panies accounts for 96.4 per cent of the market capitalisation of the ISEQ in 2004.

Company annual reports were perused to collect information on executive compensation, the structure of the board, share options, managerial ownership, a US influence and significant block ownership. Executive compensation data was collected only for the CEO. Information on the structure of the board comprises board size, the percentage of the board comprised of non-executive directors (NEDs) and chairperson/CEO duality. A company is deemed to have significant US business interests if it is quoted on a US stock exchange, has significant US subsidiaries or exports a significant amount of its products to the United States. Another indicator of US influence is the presence of a US citizen on its board of directors. We note that if a company does much of its business in the US it will usually have several US citizens on its board. The US influence is measured by an indicator variable which takes the value of 1 if the company is deemed to be susceptible to this influence and 0 otherwise. Details of managerial ownership and the proportion of equity capital held in blocks of at least 3 per cent were collected. Share prices, dividends, leverage and total assets were obtained from DATASTREAM ${ }^{\circledR}$. Information on share price and dividends is used to compute total shareholder return and abnormal returns. The market return on the ISEQ for each of the four years was also collected from DATASTREAM ${ }^{\circledR}$.

Company performance is measured by cumulative abnormal returns (CARs) over the year $t-1$. These provide a measure of performance relative to the market and should provide a superior reflection of a manager's performance than total shareholder return. If the normal level of return in the market is what executives could deliver, then returns over and above this level might be taken as to indicate exceptional managerial performance to be rewarded accordingly. Therefore, compensation may be more sensitive to abnormal performance. Abnormal returns are calculated on a monthly basis using the market model:

$\mathrm{AR}_{\mathrm{it}}=\mathrm{R}_{\mathrm{it}}-\alpha_{\mathrm{i}}-\beta_{\mathrm{i}} \mathrm{R}_{\mathrm{mt}}$

$a_{i}$ and $\beta_{i}$ are the parameters of the market model estimated by OLS regression over the 60 months prior to the period studied. The abnormal returns are then cumulated over twelve months to give an annual cumulative abnormal return (CAR), which is used as the measure of abnormal performance in the study. We supplement CAR by also using an accounting-based measure of performance return on equity (ROE).

Larger firms are more complex and should therefore have higher executive compensation levels (Rosen, 1982). The literature indentifies firm size as the dominant 
variable in determining the level of executive compensation. Accordingly, it is included here as an additional explanatory variable. Firm size can be measured as $\ln (\mathrm{TA})$ or $\ln$ (sales). Since some of the largest firms listed on the Irish stock market at the time of this study were financial services firms which do not have sales figures the natural log of total assets is used as a measure of firm size.

Two basic measures of director's compensation, the cash remuneration of the CEO and the CEO's stock options, are alternately used as the dependent variable. We concentrate on the CEO since $\mathrm{s} /$ he is the person who is most responsible for the performance of the company. Our primary measure of compensation refers to cash compensation, which is the sum of salary, pension contribution and annual bonus, and ignores stock options. Information on compensation levels was gathered from company annual reports, and its log form is used in the analysis. Previous studies have produced similar results regardless of whether they used cash compensation, total compensation (i.e. including stock options) or just salary (the component of cash compensation that is fixed at the beginning of the year). For example, Core et al. (1999) provide results pertaining to corporate governance that are completely unaffected by the use of salary, salary plus bonus, or salary plus bonus plus stockbased compensation. In addition, Finkelstein and Boyd (1998) report that simple measures of cash pay are an excellent proxy for total remuneration. On the basis of the above we decided that it was most important to have an accurate estimate of the basic compensation package available. Thus our primary measure of CEO compensation is simply salary and bonus $(\ln (P A Y))$.

However, we are cognisant that McKnight and Tomkins (1999) report higher estimates of the pay-performance sensitivity for total compensation. Thus, it is necessary to consider the role of ESOs in executive pay, particularly when examining the pay-performance relation. McKnight and Tomkins (1999) used a heuristic approach as opposed to Black-Scholes to value share options. There is difficulty in valuing executive share options using the Black-Scholes formula since they are not traded and the exercise of the options is sometimes contingent on achieving specific financial goals. Also, as pointed out by Hallock and Olson (2010), managers have differing levels of risk aversion and the Black-Scholes model assumes risk neutrality. Therefore, for most managers the Black-Scholes formula will understate the value of the ESO. Furthermore, there is evidence that some managers exercise their ESOs early and at different times to maturity, which indicates that the Black-Scholes formula (on the basis of which early exercise would never occur) is unsuitable for valuing ESOs (Hallock and Olson, 2010).

ESOs can be perceived as a substitute for managerial ownership. In our approach to the valuation we implicitly assume that all ESOs are deep-in-the-money and compute a variable equal to the natural log of the value of the firm that the ESO gives the CEO an entitlement to. Thus we gloss over the subtle differences between remuneration in the form of options and stock as outlined in Kadan and Swinkels (2008). However, our variable ESO gives an accurate estimate of the equity value that the shareholders are prepared to give up to motivate managers. It is, therefore, a better estimate of the potential cost to shareholders of ESOs than it is of the benefit to managers. We use this as the dependent variable and the same independent variables as outlined in Equation (1) in an additional model of the determinants of 
executive compensation. Accordingly, we compute the ESO as the natural log of the value of shares over which the CEO is granted options.

Theoretically, the share price is the upper bound of the value of an option. Our computation therefore overstates the value of the stock options. We confirmed this by computing option values using the Black-Scholes model for a sub-sample of our firms for which the requisite data is available and found that the Black-Scholes values are, on average, 71 per cent of our values, though both measures are positively correlated. Core et al. (1999) compute option values as 0.25 times the exercise price since simulation results suggest that sophisticated option pricing models typically produce values in this range. We also compare the valuations for our subsample with those computed using the method of Core et al. (1999) and find that these valuations have a correlation of 0.88 with ours.

\section{RESULTS}

Table 1 contains the descriptive statistics for the sample. A number of variables ROE, CAR and LEV - have outliers. In the results reported below we have kept the outliers. However, in view of the potential impact of these outliers, the empirical analysis outlined below is repeated after CAR and ROE have been winsorised at the first and $99^{\text {th }}$ percentile; LEV is winsorised at the $98^{\text {th }}$ percentile. Our results are unaffected by winsorisation.

The amount of NEDs on the board of Irish plcs has been increasing year on year, from 59 per cent in 2001 to 64 per cent in 2004. These characteristics of the NED variable are similar to those in the sample of Donnelly and Kelly (2005), who report 59 per cent of directors on Irish plcs in 2001 were NEDs. This increasing percentage may reflect the impact of the corporate governance reports which highlighted the importance of NEDs. For example, Higgs (2003) recommended that at least half the board should be comprised of NEDs. From the descriptive statistics it appears this is already the case.

The correlation coefficients between the dependent variable and all the independent variables are outlined in Table 2 . Firm size is very strongly correlated with CEO compensation, $\ln (P A Y)$. Board size is, not surprisingly, highly correlated $(\rho=$ $0.5)$ with the CEO's pay. Managerial ownership is negatively correlated with compensation. Thus, management ownership may be an alternative incentive method to compensation. Another interpretation is that large companies have low levels of managerial ownership, giving rise to a spurious correlation between managerial ownership and compensation. The correlation $(\rho=0.39)$ between both the salaryand option-based compensation variables is significant. This suggests that salary plus bonus is a reasonable though imperfect proxy for total remuneration. Our primary measure of CEO compensation, $\ln (P A Y)$, is also significantly correlated with our US variable $(\rho=0.34)$ in line with predictions. ESO has the same significant correlations with the independent variables as those of $\ln (P A Y)$. It also has a significant positive correlation with DUAL, which implies that CEOs who are not the chairpersons of their companies have more stock options then those who are. This is perhaps not surprising since combining the roles (CEO/chair duality) often stems 
Pay, Performance and Governance in Irish plcs

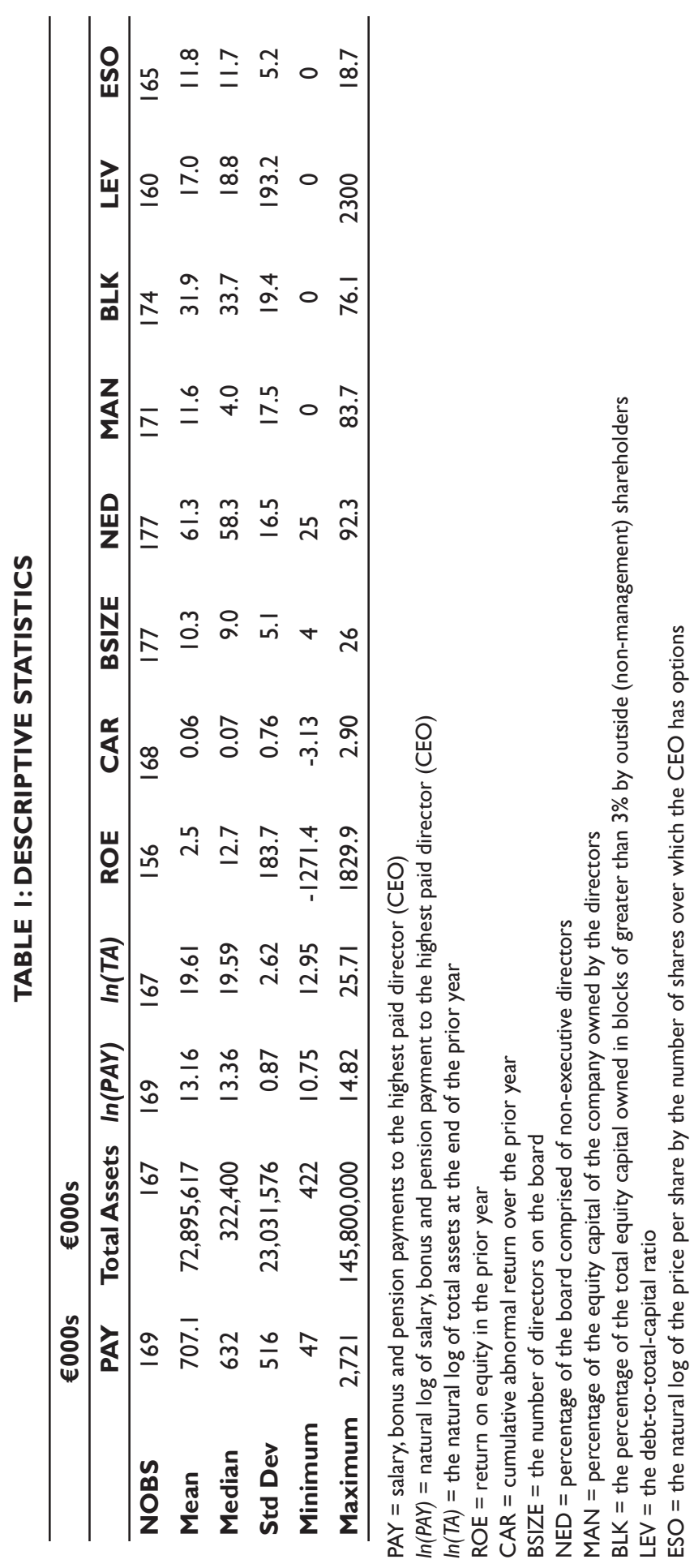


Cao, Donnelly and McCarthy

TABLE 2: CORRELATION MATRIX

\begin{tabular}{|c|c|c|c|c|c|c|c|c|c|c|c|c|}
\hline & $\ln (P A Y)$ & ESO & $\ln (T A)$ & CAR & ROE & BSIZE & NED & MAN & BLK & LEV & DUAL & US \\
\hline ESO & $0.39^{*}$ & & & & & & & & & & & \\
\hline $\ln (T A)$ & $0.80^{*}$ & $0.38^{*}$ & & & & & & & & & & \\
\hline CAR & -0.09 & -0.10 & -0.07 & & & & & & & & & \\
\hline ROE & 0.00 & 0.00 & 0.01 & -0.10 & & & & & & & & \\
\hline BSIZE & $0.50^{*}$ & $0.34^{*}$ & $0.50^{*}$ & -0.03 & 0.00 & & & & & & & \\
\hline NED & -0.04 & 0.14 & 0.13 & 0.13 & -0.03 & $0.39^{*}$ & & & & & & \\
\hline MAN & $-0.21^{*}$ & $-0.37^{*}$ & $-0.33^{*}$ & 0.05 & -0.04 & $-0.20^{*}$ & -0.16 & & & & & \\
\hline BLK & -0.11 & -0.10 & -0.11 & 0.10 & 0.02 & 0.01 & 0.03 & $-0.28^{*}$ & & & & \\
\hline LEV & -0.07 & 0.07 & -0.08 & -0.05 & -0.03 & -0.03 & -0.07 & -0.09 & -0.04 & & & \\
\hline DUAL & 0.05 & $0.36^{*}$ & 0.01 & -0.05 & 0.00 & 0.15 & $0.26^{*}$ & -0.12 & $-0.16^{*}$ & 0.06 & & \\
\hline US & $0.34^{*}$ & $0.35^{*}$ & $0.31^{*}$ & -0.07 & -0.06 & $0.31^{*}$ & $0.16^{*}$ & -0.08 & $-0.21^{*}$ & -0.04 & -0.03 & \\
\hline FIN & $0.18^{*}$ & $0.22^{*}$ & $0.64^{*}$ & 0.00 & 0.03 & $0.15^{*}$ & $0.24^{*}$ & -0.09 & $-0.26^{*}$ & 0.04 & 0.15 & 0.13 \\
\hline
\end{tabular}

${ }^{*}$ Indicates significance at the $5 \%$ level.Variables are as defined in Table I above and in Equation (I) in the text

from management entrenchment through share ownership and there is little point in trying to incentivise someone who already has a significant shareholding in a company with stock options. The highest correlation between the independent variables is that between $\ln (\mathrm{TA})$ and FIN - this is not surprising since financial firms were amongst the largest in the market over the period studied. This may be a source of multicollinearity which potentially induces a type 2 error and should be borne in mind when interpreting the results below. We note that US is positively correlated with $\ln (\mathrm{TA}), \mathrm{BSIZE}, \mathrm{NED}$ and FIN, and negatively correlated with MAN.

Table 3 reports the results of OLS regressions where the model outlined in Equation (1) is used to explain compensation. We use clustered standard errors to control for the dependence induced by the same firm appearing more than once in the sample over the period studied. The coefficient on performance, $\beta_{2}$, is not significant regardless of how it is measured, thus we have no support for $\mathrm{H}_{1}$. The coefficients on firm size as measured by total assets are significantly positive, supporting $\mathrm{H}_{2}$. The finding that firm size is an important variable in explaining compensation levels is consistent with many previous studies.

The coefficients on board size are also significantly positive. Prior literature has argued that larger boards are not as effective monitors as smaller boards in Ireland (e.g. Donnelly and Kelly, 2005). Thus, we interpret the significance of $\beta_{3}$ as evidence of a weaker board allowing higher remuneration - this supports $\mathrm{H}_{3}$.

The results reveal that pay is a decreasing function of the proportion of the board comprised of NEDs. Thus it suggests that NEDs perform a monitoring role and mitigate excessive compensation, also supporting $\mathrm{H}_{3}$.

Additional regression models estimate the interaction between governance variables and performance. However, since these provide no support for $\mathrm{H}_{4}$ - that improved governance has a positive influence on the pay-performance relation they are not tabulated here. 
Pay, Performance and Governance in Irish plcs

TABLE 3: COMPENSATION AND PERFORMANCE - REGRESSION ANALYSIS

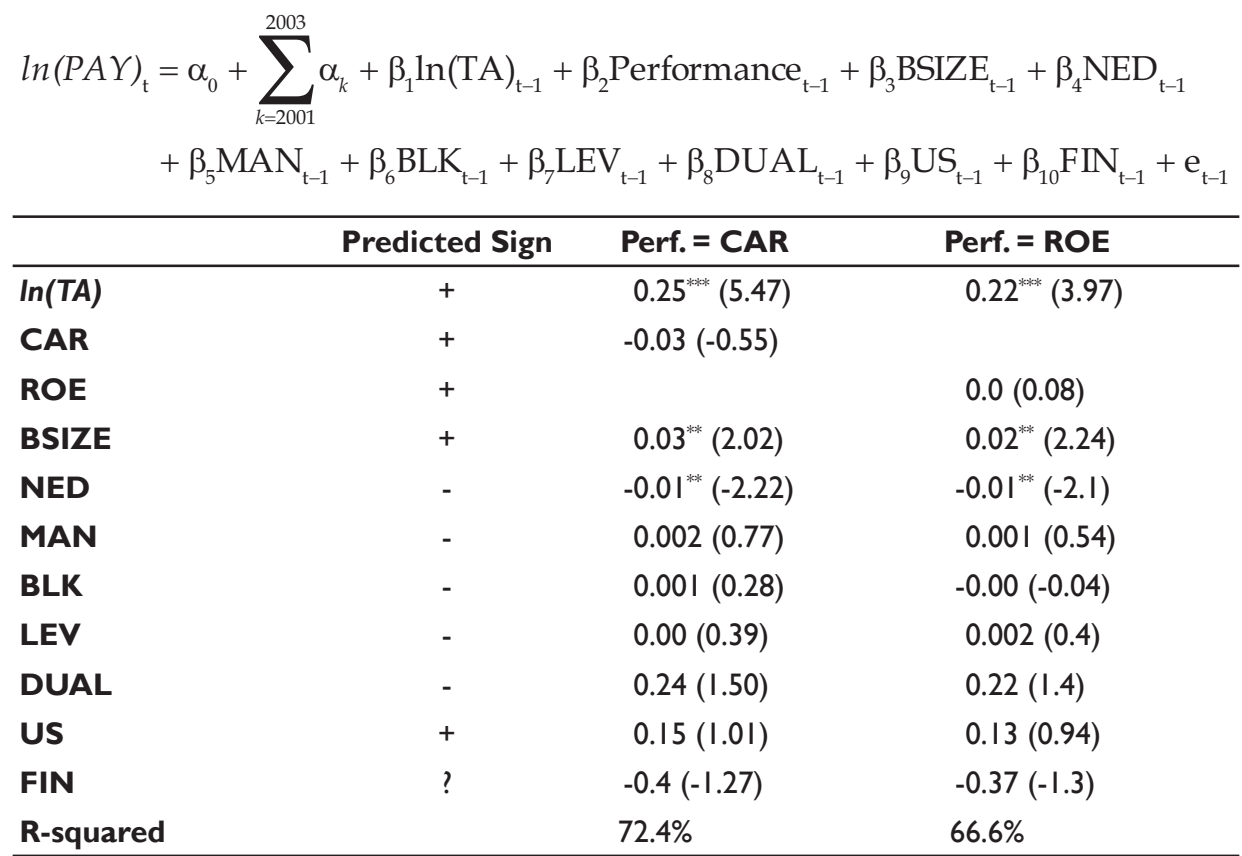

Clustered standard errors are in parentheses

Hypotheses tests are two-tailed unless the direction of the predicted relation is specified

${ }^{*},{ }^{* * *}$ and ${ }^{* * * *}$ indicate significance at the $10 \%, 5 \%$ and $1 \%$ levels respectively

$\ln (P A Y)=$ remuneration of highest paid director (CEO)

Performance $=$ cumulative abnormal return $(C A R)$ or ROE

$\ln (T A)=$ the natural logarithm of total assets

$\mathrm{BSIZE}=$ the number of directors on the board

NED = the proportion of the board comprised of non-executive directors

MAN = the percentage of the total equity capital owned by the executive directors

$\mathrm{BLK}=$ the percentage of the total equity capital owned in blocks of greater than $3 \%$ by outside (non-management) shareholders

LEV = the debt-to-total-capital ratio

DUAL = a dummy variable which takes the value of I when the positions of chairperson and CEO are held by different persons

US = an indicator variable which is I if the company has significant US business interests or a US national on its board and zero otherwise

$\mathrm{FIN}=$ an indicator variable which takes the value $I$ if firm $i$ is a financial or property firm and zero otherwise

$a_{k}$ are dummy variables representing the years 200I, 2002 and 2003; their coefficients have been omitted from the table in the interest of brevity

It was reported in prior literature that there was an asymmetric relationship between pay and performance. When returns are high, pay increases; however, when returns decline pay does not decline comparably with the fall in return, if indeed it falls at all. This is explored in a separate regression with the use of dummy variables to separate positive and negative performance. D1 is coded as 1 when return is positive (zero otherwise); D2 is 1 when return is negative, zero otherwise (see Equation (2) above). Thus, we predict a positive coefficient on CAR*D1 
Cao, Donnelly and McCarthy

TABLE 4:TEST OF ASYMMETRIC RELATION OF BASIC COMPENSATION WITH PERFORMANCE

\begin{tabular}{|c|c|c|c|}
\hline \multicolumn{4}{|c|}{$\begin{array}{l}+\beta_{4} \mathrm{BSIZE}_{\mathrm{t}-1}+\beta_{5} \mathrm{NED}_{\mathrm{t}-1}+\beta_{6} \mathrm{MAN}_{\mathrm{t}-1}+\beta_{7} \mathrm{BLK}_{\mathrm{t}-1}+\beta_{8} \mathrm{LEV}_{\mathrm{t}-1}+\beta_{9} \mathrm{DUAL}_{\mathrm{t}-1} \\
+\beta_{10} \mathrm{US}_{\mathrm{t}-1}+\beta_{11} \mathrm{FIN}_{\mathrm{t}-1}+\mathrm{e}_{\mathrm{t}-1}\end{array}$} \\
\hline & Predicted Sign & Perf. $=$ CAR & Perf. = ROE \\
\hline $\ln (T A)$ & + & $0.25^{\text {*ate }}(5.2 \mathrm{I})$ & $0.22^{* *}(3.78)$ \\
\hline Negative Performance & 0 & $0.05(0.63)$ & $-0.00(-0.43)$ \\
\hline Positive Performance & + & $-0.11(-1.04)$ & $0.00(0.57)$ \\
\hline BSIZE & + & $0.03^{*}(1.87)$ & $0.02^{* * *}(2.26)$ \\
\hline NED & - & $-0.01^{* * *}(-2.14)$ & $-0.01^{* *}(-2.12)$ \\
\hline MAN & - & $0.002(0.95)$ & $0.002(0.56)$ \\
\hline BLK & - & 0.001 (0.29) & $-0.00(-0.01)$ \\
\hline LEV & - & $0.00(0.37)$ & $0.002(0.40)$ \\
\hline DUAL & - & $0.25(1.57)$ & $0.22(1.38)$ \\
\hline US & + & $0.17(1.19)$ & $0.13(0.92)$ \\
\hline FIN & ? & $-0.41(-1.26)$ & $-0.38(-1.3)$ \\
\hline R-squared & & $71.64 \%$ & $66.7 \%$ \\
\hline
\end{tabular}

Clustered standard errors are in parentheses

Hypotheses are based on two-tailed tests

${ }^{*},{ }^{* *}$ and ${ }^{* * * *}$ indicate significance at the $10 \%, 5 \%$ and $1 \%$ levels respectively

$\ln (P A Y)=$ remuneration of the CEO

Perf. $=$ return on equity $(\mathrm{ROE})$ or cumulative abnormal return $(C A R)$

$D I$ is a dummy variable which takes the value of I when ROE (CAR) is negative

$D 2$ is a dummy variable which takes the value of I when ROE (CAR) is $\geq 0$

$\mathrm{BSIZE}=$ the number of directors on the board

NED = the proportion of the board comprised of non-executive directors

MAN = the percentage of the total equity capital owned by the executive directors

BLK $=$ the percentage of the total equity capital owned in blocks of greater than $3 \%$ by outside (non-management) shareholders

LEV = the debt-to-total-capital ratio

DUAL = a dummy variable which takes the value of I when the positions of chairperson and CEO are held by different persons

US = an indicator variable which is I if the company has significant US business interests or a US national on its board and zero otherwise

$\mathrm{FIN}=$ an indicator variable which takes the value $\mathrm{I}$ if firm $i$ is a financial or property firm and zero otherwise $a_{k}$ are dummy variables representing the years 200I, 2002 and 2003; their coefficients have been omitted from the table in the interest of brevity

in Equation (2). The coefficient on $C A R^{*} \mathrm{D} 2$ is not expected to differ from zero. The results of these additional regressions are presented in Table 4 . Here the coefficient values on performance are small and clustered around either side of zero. The 
Pay, Performance and Governance in Irish plcs

TABLE 5: EXECUTIVE STOCK OPTIONS AND PERFORMANCE REGRESSION ANALYSIS

\begin{tabular}{|c|c|c|c|}
\hline & Predicted Value & Perf. = CAR & Perf. $=$ ROE \\
\hline $\ln (T A)$ & + & $0.53^{* *}(2.0)$ & $0.40(1.36)$ \\
\hline CAR & + & $-0.11(-0.30)$ & \\
\hline ROE & + & & $0.001(1.37)$ \\
\hline BSIZE & + & $0.12(0.88)$ & $0.07(0.56)$ \\
\hline NED & - & $-0.05^{*}(-1.76)$ & $-0.04(-1.54)$ \\
\hline MAN & - & $-0.1 I^{* *}(2.32)$ & $-0.1 I^{* * *}(-2.49)$ \\
\hline BLK & - & $-0.04(-1.22)$ & $-0.05(-1.49)$ \\
\hline LEV & - & $-0.00(0.96)$ & $0.04(1.10)$ \\
\hline DUAL & - & $5.22^{* *}(2.43)$ & $5.06^{* *}(2.4)$ \\
\hline US & + & $2.74^{* *}(2.36)$ & $2.89^{* *}(2.50)$ \\
\hline FIN & $?$ & $-3.11^{*}(-1.85)$ & $-4.49^{* * *}(-2.26)$ \\
\hline R-squared & & $47.9 \%$ & $48.8 \%$ \\
\hline
\end{tabular}

Clustered standard errors are in parentheses

Hypotheses tests are based on two-tailed tests

${ }^{*},{ }^{* *}$ and ${ }^{* * * *}$ indicate significance at the $10 \%, 5 \%$ and $1 \%$ levels respectively

ESO is the natural log of value of the share capital of the company allocated to executive stock options for the CEO

Performance $=$ total shareholder return or abnormal return

$\mathrm{BSIZE}=$ the number of directors on the board

NED $=$ the proportion of the board comprised of non-executive directors

MAN = the percentage of the total equity capital owned by the executive directors

BLK = the percentage of the total equity capital owned in blocks of greater than $3 \%$ by outside (non-management) shareholders

LEV = the debt-to-total-capital ratio

DUAL = a dummy variable which takes the value of I when the positions of chairperson and CEO are held by different persons

US = an indicator variable which is I if the company has significant US business interests or a US national on its board and zero otherwise

$\mathrm{FIN}=$ an indicator variable which takes the value $\mathrm{I}$ if firm $i$ is a financial or property firm and zero otherwise $a_{k}$ are dummy variables representing the years 200I, 2002 and 2003; their coefficients have been omitted from the table in the interest of brevity

results provide no evidence that there is an asymmetric relationship between cash compensation and performance $-\mathrm{H}_{6}$ is not supported.

We now turn to an explanation of compensation in the form of ESOs. Table 5 contains the output from regressions which have ESO as the dependent variable. $\ln (\mathrm{TA})$ and BSIZE are no longer significant. NED has its significance attenuated but remains significant at the 10 per cent level in one of the models. The US variable is now more significant and is in keeping with the correlation analysis. Thus the US influence on 
Cao, Donnelly and McCarthy

\section{TABLE 6: CHIEF EXECUTIVE'S STOCK OPTIONS AND DIFFERENTIAL PERFORMANCE}

\begin{tabular}{|c|c|c|c|}
\hline \multicolumn{4}{|c|}{$\begin{array}{l}+\beta_{4} \mathrm{BSIZE}_{\mathrm{t}-1}+\beta_{5} \mathrm{NED}_{\mathrm{t}-1}+\beta_{6} \mathrm{MAN}_{\mathrm{t}-1}+\beta_{7} \mathrm{BLK}_{\mathrm{t}-1}+\beta_{8} \mathrm{LEV}_{\mathrm{t}-1}+\beta_{9} \mathrm{DUAL}_{\mathrm{t}-1} \\
+\beta_{10} \mathrm{US}+\mathrm{e}\end{array}$} \\
\hline & Predicted Sign & Perf. = CAR & Perf. = ROE \\
\hline $\ln (T A)$ & + & $0.52^{*}(1.92)$ & $0.45(\mathrm{I} .5 \mathrm{I})$ \\
\hline Negative Performance & 0 & $0.09(0.12)$ & $-0.002(-0.78)$ \\
\hline Positive Performance & + & $-0.33(-0.40)$ & $0.002^{*}(1.87)$ \\
\hline BSIZE & + & $0.11(0.82)$ & $0.08(0.58)$ \\
\hline NED & - & $-0.05^{*}(-1.67)$ & $-0.05(-1.55)$ \\
\hline MAN & - & $-0.1 I^{* *}(-2.29)$ & $-0.1 I^{* *}(-2.37)$ \\
\hline BLK & - & $-0.04(-1.22)$ & $-0.04(-1.40)$ \\
\hline LEV & - & $0.00(0.96)$ & $0.04(1.09)$ \\
\hline DUAL & - & $5.25^{* *}(2.42)$ & $5.04^{* *}(2.37)$ \\
\hline US & + & $2.8 I^{* *}(2.27)$ & $2.86^{* *}(2.47)$ \\
\hline FIN & $?$ & $-3.13^{*}(-1.83)$ & $-4.6 I^{*}(-2.27)$ \\
\hline R-squared & & $47.9 \%$ & $49.2 \%$ \\
\hline
\end{tabular}

Clustered standard errors are in parentheses

Hypotheses are based on two-tailed tests

${ }^{*}, * *$ and ${ }^{* * *}$ indicate significance at the $10 \%, 5 \%$ and $1 \%$ levels respectively

ESO is the natural log of value of the share capital of the company allocated to executive stock options for the CEO

Perf. $=$ return on equity $(\mathrm{ROE})$ or cumulative abnormal return $(\mathrm{CAR})$

$D I$ is a dummy variable which takes the value of I when ROE (CAR) is negative

$D 2$ is a dummy variable which takes the value of I when ROE (CAR) is $\geq 0$

$\mathrm{BSIZE}=$ the number of directors on the board

NED = the proportion of the board comprised of non-executive directors

MAN = the percentage of the total equity capital owned by the executive directors

$\mathrm{BLK}=$ the percentage of the total equity capital owned in blocks of greater than $3 \%$ by outside (non-management) shareholders

LEV = the debt-to-total-capital ratio

DUAL = a dummy variable which takes the value of I when the positions of chairperson and CEO are held by different persons

US = an indicator variable which is I if the company has significant US business interests or a US national on its board and zero otherwise

FIN = an indicator variable which takes the value $\mathrm{I}$ if firm $i$ is a financial or property firm and zero otherwise $a_{k}$ are dummy variables representing the years 200I, 2002 and 2003; their coefficients have been omitted from the table in the interest of brevity

the level of CEO compensation is generally confined to performance-related pay. Since option-based compensation originated in the US and US companies used this method of compensation before other countries, the finding that the US influence is more apparent in contingent-based compensation is not surprising. 
Separating the roles of the CEO and chairperson appears to increase payment in the form of ESOs to the CEO. This is counterintuitive but further investigation reveals that the average director ownership of companies which combine the roles of CEO and chair is 70 per cent larger than director ownership when the roles are separate. This difference is statistically significant. Thus, the positive coefficient on DUAL can be interpreted as evidence of a substitution effect between managerial ownership and the use of ESOs. The coefficient on managerial ownership itself is significantly negative when ESO is the dependent variable lending further credence to this interpretation. FIN is significantly negative in Table 5, indicating that financial firms give less of their value away in options than other firms.

A similar analysis to test $\mathrm{H}_{6}$ for ESOs is undertaken and the results are outlined in Table 6. There is no evidence of asymmetry in the relation between ESOs and performance when the latter is measured by CAR. The results are thus consistent with $\ln (P A Y)$ in this respect. However, there is some evidence of asymmetry in the relation between ROE and ESOs with an insignificant relation when ROE is negative and a weakly significant positive relationship when ROE is positive.

\section{CONCLUSION}

The objective of this paper is to investigate the determinants of executive compensation levels in an Irish context. The research focuses on two measures of performance - abnormal returns and return on equity. Compensation is defined alternately as cash compensation (salary pension and bonus) or executive stock options.

Firm size is a dominant variable in explaining the level of pay for CEOs. This result is stronger for $\ln (P A Y)$ than for ESO. We also find stronger connections with US business practices is positively correlated with increased compensation for Irish CEOs. This finding is confirmed in the regression analysis only when ESO is the dependent variable. Thus, we infer that exposure to US business practices influences the form as well as the size of compensation for Irish CEOs.

The board structure variables are related to compensation levels in the manner predicted and the results are generally consistent regardless of whether compensation is measured by $\ln (P A Y)$ or ESO. The proportion of the board comprised of NEDs has a negative relation and board size has a positive relation with compensation to the CEO. These results suggest that monitoring boards serve to reduce compensation. The only corporate governance variable that is related to ESO in a manner contrary to our prediction is DUAL. Further investigation shows the combination of the CEO and chairperson roles is associated with very high levels of management ownership. Thus, firms that combine the roles of CEO and chairperson are owner controlled and do not have to incentivise their management with ESOs. Overall, the results pertaining to our corporate governance variables are good news for regulators since they support the notion that better governance curbs excessive executive remuneration.

Our results do not suggest a strong relation between performance and pay. Neither do they point to an asymmetric relation between compensation and performance, although there is some evidence of such asymmetry for ESOs and ROE. 
Cao, Donnelly and McCarthy

Here better performance is rewarded with more ESOs but when ROE is negative it is not related to ESO compensation. We don't find any evidence of corporate governance influencing the pay-performance relation. This finding is less encouraging from a corporate governance perspective.

A caveat to the above is that the measure of compensation in the form of ESOs is heuristic. However, we can be categorical in stating that Irish plcs grant options over more of their value when they are larger, have a US connection or have weak corporate governance mechanisms to provide monitoring on behalf of shareholders. Another potential limitation of the study is that it is motivated mainly by theories of agency and managerialism. It should be recognised that other theories pertaining to the managerial labour market and social comparison and equity theories (e.g. Ezzamel and Watson, 2002) can help explain executive compensation. In addition, since managers face more risk than their diversified shareholders an element of insurance in terms of a fixed salary unrelated to performance is justified.

\section{ACKNOWLEDGMENTS}

This paper has benefited from the constructive comments of two anonymous reviewers; all remaining errors are our own.

\section{ENDNOTES}

1 In 2007, Bank of Ireland's CEO received almost $€ 4$ million in annual compensation, which was the feature of much media interest and criticism. This issue has refused to go away in the light of the subsequent bailout of the bank by the Irish government.

2 Mosney Irish Holidays is included in the list but has a market capitalisation of zero so is ignored.

3 The five companies included have a combined market capitalisation equal to over 75 per cent of the three minor markets and are larger than most of the companies on the Official List whose data we did not gain access to.

\section{REFERENCES}

Allen, M. (1981). Power and Privilege in the Large Corporation: Corporate Control and Managerial Compensation, American Journal of Sociology, Vol. 86, No. 5, pp. 1112-1123.

Baker, G. and Hall, B. (2002). CEO Incentives and Firm Size, working paper, Harvard University.

Baker, G., Jensen, M. and Murphy, K. (1988). Compensation and Incentives: Practice vs. Theory, Journal of Finance, Vol. 43, No. 3, pp. 593-616.

Becker, B. (2006). Wealth and Executive Compensation, Journal of Finance, Vol. 61, No. 1, pp. 379-397.

Benito, A. and Conyon, M. (1999). The Governance of Directors' Pay: Evidence from UK Companies, Journal of Management and Governance, Vol. 3, pp. 117-136.

Boyd, B. (1994). Board Control and CEO Compensation, Strategic Management Journal, Vol. 15, No. 5, pp. 335-344.

Byard, D. and Li, Y. (2005). The Impact of Directors' Option Compensation on Their Independence, February, available from SSRN: <http:// ssrn.com/abstract=683385>, accessed 1 August 2013. 
Pay, Performance and Governance in Irish plcs

Cadbury, A. (1992). Report of the Committee on the Financial Aspects of Corporate Governance, London: Gee.

Conyon, M. and Leech, D. (1994). Top Pay, Company Performance, Company Performance and Corporate Governance, Oxford Bulletin of Economics E Statistics, Vol. 56, No. 3, pp. 229-247.

Conyon, M. and Murphy, K. (2000). The Prince and the Pauper? CEO Pay in the United States and United Kingdom, Economic Journal, Vol. 110, November, pp. F640-F671.

Conyon, M. and Peck, S. (1998). Board Control, Remuneration Committees, and Top Management Compensation, Academy of Management Journal, Vol. 41, No. 2, pp. 146-157.

Conyon, M., Peck, S., Read, L. and Sadler, G. (2000). The Structure of Executive Compensation Contracts: UK Evidence, Long Range Planning, Vol. 33, No. 4, pp. 478-503.

Core, J., Holthausen, R. and Larcker, D. (1999). Corporate Governance, Chief Executive Officer Compensation, and Firm Performance, Journal of Financial Economics, Vol. 51, No. 3, pp. 371-406.

Cosh, A. (1975). The Remuneration of Chief Executive Officers in the UK, Economic Journal, Vol. 85, March, pp. 75-94.

Dong, M. and Ozkan, A. (2008). Institutional Investors and Director Pay: An Empirical Study of UK Companies, Journal of Multinational Financial Management, Vol. 18, No. 1, pp. 16-29.

Donnelly, R. and Kelly, P. (2005). Ownership and Board Structures in Irish Plcs, European Management Journal, Vol. 23, No. 6, pp. 730-740.

Ezzamel, M. and Watson, R. (2002). Pay Comparability across and within UK Boards: An Empirical Analysis of the Cash Pay Awards to CEOs and Other Board Members, Journal of Management Studies, Vol. 39, No. 2, pp. 207-232.

Fernandes, N. (2008). EC - Board Compensation and Firm Performance: The Role of 'Independent' Board Members, Journal of Multinational Financial Management, Vol. 18, No. 1, pp. 30-44.

Financial Reporting Council (2010). UK Corporate Governance Code, London: Financial Reporting Council.

Finkelstein, S. and Boyd, B. (1998). How Much Does the CEO Matter? The Role of Managerial Discretion in the Setting of CEO Compensation, Academy of Management Journal, Vol. 41, No. 2, pp. 179-199.

Franks, J., Mayer, C. and Renneboog, L. (2001). Who Disciplines Management in Poorly Performing Companies?, Journal of Financial Intermediation, Vol. 10, Nos. 3-4, pp. 209-248.

Garen, J. (1994). Executive Compensation and Principal-Agent Theory, Journal of Political Economy, Vol. 102, No. 6, pp. 1175-1199.

Girma, S., Thompson, S. and Wright P. (2007). Corporate Governance Reforms and Executive Compensation Determination: Evidence from the UK, Manchester School, Vol. 75, No. 1 , pp. 65-81.

Greenbury, R. (1995). Directors Remuneration: Report of a Study Group Chaired by Sir Richard Greenbury, London: Gee.

Gregg, P., Jewell, S. and Tonks, I. (2005). Executive Pay and Performance in the UK 1994-2002, working paper, University of Exeter, available from: <https://eric.exeter.ac.uk/repository/bitstream/handle/10036/22200/0505.pdf?sequence=1>, accessed 1 August 2013.

Gregg, P., Machin, S. and Szymanski, S. (1993). The Disappearing Relationship between Directors' Pay and Corporate Performance, British Journal of Industrial Relations, Vol. 31, No. 1, pp. 1-9.

Hallock, K. and Olson, C. (2010). New Data for Answering Old Questions Regarding Employee Stock Options, in K. Abraham, J. Spletzer and M. Harper (eds.), Labor in the New Economy, London: University of Chicago Press for the National Bureau of Economic Research. 
Cao, Donnelly and McCarthy

Hambrick, D. and Finkelstein, S. (1995). The Effects of Ownership Structure on Conditions at the Top: The Case of CEO Pay Raises, Strategic Management Journal, Vol. 16, No. 3, pp. 175-193.

Hartzell, J. and Starks, L. (2003). Institutional Investors and Executive Compensation, Journal of Finance, Vol. 58, No. 6, pp. 2351-2374.

Haubrich, J. (1994). Risk Aversion, Performance Pay, and the Principal-Agent Problem, Journal of Political Economy, Vol. 102, No. 2, pp. 258-276.

Higgs, D. (2003). Review of the Role and Effectiveness of Non-Executive Directors, London: Department of Trade and Industry.

Holderness, C. and Sheehan, D. (1988) The Role of Majority Shareholders in Publicly Held Corporations: An Exploratory Analysis, Journal of Financial Economics, Vol. 20, JanuaryMarch, pp. 317-346.

Holmstrom, B. (1979). Moral Hazard and Observability, Bell Journal of Economics, Vol. 10, No. 1, pp. 74-91.

Irish Stock Exchange (2003). Annual Statistical Review, Dublin: Irish Stock Exchange.

Jensen, M. and Murphy, K. (1990a). CEO Incentives - It's Not How Much You Pay, But How, Harvard Business Review, May-June, pp. 138-149.

Jensen, M. and Murphy, K. (1990b). Performance Pay and Top Management Incentives, Journal of Political Economy, Vol. 98, No. 2, pp. 225-264.

Kadan, O. and Swinkels, J. (2008). Stocks or Options? Moral Hazard, Firm Viability, and the Design of Compensation, Review of Financial Studies, Vol. 21, No. 1, pp. 451-482.

Kostiuk, P. (1990). Firm Size and Executive Compensation, Journal of Human Resources, Vol. 25, No. 1, pp. 90-105.

Lazear, E. (1989). Pay Equality and Industrial Politics, Journal of Political Economy, Vol. 97, No. 3, pp. 561-80.

Main, B., Bruce, A. and Buck, T. (1996). Total Board Remuneration and Company Performance, Economic Journal, Vol. 106, November, pp. 1627-1644.

McKnight, P. and Tomkins, C. (1999). Top Executive Pay in the United Kingdom: A Corporate Governance Dilemma, International Journal of the Economics of Business, Vol. 6, No. 2, pp. 223-243.

Murphy, K. (1985). Corporate Performance and Managerial Remuneration: An Empirical Analysis, Journal of Accounting and Economics, Vol. 7, Nos. 1-3, pp. 11-42.

Ozkan, N. (2007). Do Corporate Governance Mechanisms Influence CEO Compensation? An Empirical Investigation of UK Companies, Journal of Multinational Financial Management, Vol. 17, No. 5, pp. 349-364.

Rajgopal, S., Shevlin, T. and Zamora, V. (2006). CEOs' Outside Employment Opportunities and the Lack of Relative Performance Evaluation in Compensation Contracts, Journal of Finance, Vol. 61, No. 4, pp. 1813-1844.

Rosen, S. (1982). Authority, Control, and the Distribution of Earnings, Bell Journal of Economics, Vol. 13, No. 2, pp. 311-323.

Rosen, S. (1990). Contracts and the Market for Executives, NBER working paper no. 3542, available from: <http://www.nber.org/papers/w3542>, accessed 1 August 2013.

Sapp, S. (2008). The Impact of Corporate Governance on Executive Compensation, European Financial Management, Vol. 14, No. 4, pp. 710-746.

Tosi, H., Werner, S., Katz, J. and Gomez-Mejia, L. (2000). How Much Does Performance Matter? A Meta-Analysis of CEO Pay Studies, Journal of Management, Vol. 26, No. 2, pp. 301-339. 